\title{
Хрониканаучной жизни
}

УДК 001.32

DOI: $10.22378 /$ he.2019-4-2.386-398

\section{«ЖАЛЬ, ЧТО МЫ ВСЕГДА ОСОЗНАЕМ ПОТЕРИ СПУСТЯ ВРЕМЯ»}

\section{Э.В. Мигранова}

Ордена Знак Почета Институт истории, языка и литературы УФИЦ РАН

Уфа, Российская Федерачия

mig.el@mail.ru

Данная мемориальная статья посвящена описанию жизни, научной и педагогической деятельности ученого-этнолога Рифа Исмагиловича Якупова, безвременно ушедшего из жизни, внесшего значительный вклад в исследование теоретических вопросов теории этноса, в разрешение проблемы формирования и исторического развития тептярей, в изучение архивного дела в Республике Башкортостан и других актуальных проблем современной этнологической науки.

Ключевые слова: Риф Исмагилович Якупов, ученый, этнолог, педагог, теория этноса, тептяри.

Для цитирования: Мигранова Э.В. «Жаль, что мы всегда осознаем потери спустя время» // Историческая этнология. 2019. Т. 4, № 2. С. 386-398. DOI: 10.22378/he.2019-4-2.386-398

«Отвечай добром на зло, дабы иссушить корень зла».

Он был добрым и обаятельным человеком. Таким мы его и будем помнить...

Не дожив меньше месяца до своего 60-летия, 11 июля 2019 г. ушел из жизни видный ученый-этнолог, доктор исторических наук, профессор, ведущий научный сотрудник Ордена Знак Почета Института истории, языка и литературы УФИЦ РАН Риф Исмагилович Якупов.

Хотелось бы, чтобы в рассказе о нем сквозь равнодушные череду дат и событий проступил портрет живого человека, друга, наставника, коллеги - человека с тонким умом и острым пером, с огромным чувством юмора и обостренным чувством справедливости... 
Риф Якупов родился 6 августа 1959 г. в городе Стерлитамаке в семье служащих. Учеба Р.И. Якупова на историкоанглийском факультете Башкирского государственного педагогического института пришлась на 1980-1985 гг. В институт он поступил уже зрелым человеком, успев после окончания школы № 11 г. Уфы (история которой ведет свое начало от Уфимской мужской гимназии) поработать и лаборантом в одном из НИИ, и отслужить в рядах Советской Армии (в разведывательном батальоне в г.Тоцке). Риф Исмагилович отмечал, что навыки разведчика, полученные в армии, впо-

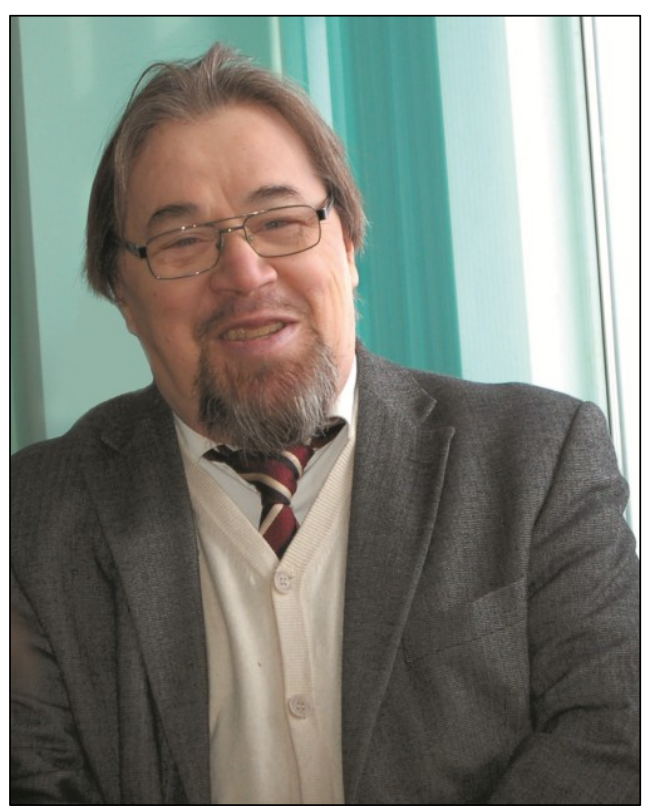

Р.И. Якупов. 8 марта 2016 г. следствии немало помогали ему в исследовательской и полевой работе, особенно в беседах с информаторами, заставляли его в экспедициях подмечать мельчайшие детали и подробности. Риф Исмагилович особо подчеркивал «домашность» и какую-то особую камерность факультета, расположенного в старинном здании, в отдалении от основных учебных корпусов. Обитающий в те годы здесь добрый дух учености и атмосфера демократизма, взаимоуважения и доброжелательности были, конечно, же, в первую очередь, заслугой преподавательского состава. Негласная состязательность кафедр «английского» и «истории» стимулировала познавательную деятельность студентов, учила их размышлять, отстаивать свое мнение. Преподаватели «историки» не упускали момента пожурить студентов за слабое владение языком, а «англичане» за незнание исторического материала, если таковое обнаруживалось. Впрочем, делалось это ненавязчиво, без упреков и репрессий. Отсюда и прекрасное знание языка (Р.И. Якупов легко писал статьи на английском), и историческое мышление, и любовь к истории как к процессу, ставшая впоследствии смыслом жизни Рифа Исмагиловича.

После окончания вуза Р.И. Якупов, проработав год в школе № 103, был приглашен на работу в родной пединститут, где прошел путь от ассистента до доцента и профессора. Сначала он с воодушевлением берется за создание телепресс-центра при БГПИ и успешно руководит его работой, одновременно работает на кафедрах Истории СССР и истории КПСС (позднее истории Отечества БГПУ), читает лекции и ведет спецкурсы по общей этнологии и этнографии народов Волго-Уральского региона, исто- 
риографии, источниковедению и прочим предметам. Талантливый организатор науки Р.И. Якупов внес значительный вклад в формирование системы подготовки профессиональных историков и этнологов, а как способный лектор и педагог, он способствовал становлению и творческому росту молодого поколения ученых.

В 1989 г. Якупов Р.И. поступает в аспирантуру Уфимского научного центра РАН по специальности этнология в Отдел народов Урала (ОНУ). Его научным руководителем, разумеется, становится Р.Г. Кузеев, который представлял собой огромную величину, глыбу в отечественной и мировой этнографии. Первое знакомство Р.И. Якупова с научными взглядами вицепрезидента Академии наук Республики Башкортостан, члена-корреспондента РАН, профессора Р.Г. Кузеева произошло еще на истфаке, где последний читал курс общей этнологии. Лекции Раиля Гумеровича, проходившие раз в неделю, каждый раз становились событием; в аудитории стояла полная тишина, было слышно как «пролетает муха», темы и манера преподавания настолько увлекали студентов, что лектору не нужны были никакие особые приемы привлечения внимания слушателей. Уже в студенческие годы Р.И. Якупов начал серьезно заниматься исследовательской работой под руководством Р.Г. Кузеева. Вот цитата из рекомендации на Якупова, написанная Раилем Гумеровичем. «Риф Якупов - один из моих учеников. Еще во время выполнения курсовых и исследовательских проектов я обратил внимание на его способности к философии, умение делать обобщения, неординарность мышления. За время совместной работы Р. Якупов не только проявил незаурядные качества исследователя, но и большие организационные способности». Эти слова мэтра дорогого стоят.

Значителен вклад Р.И. Якупова в деятельность Музея археологии и этнографии. Он был автором концепции новой экспозиции Музея в начале 1990-х гг., ходил по залам буквально с миллиметровкой и поделился данным опытом в статье «Научная концепция этнографической экспозиции МАЭ: из опыта работы», опубликованной в сборнике «Музееведение» (1995). Ему принадлежит авторство оформления музейных выставок по традиционным верованиям и религиям народов Южного Урала. В 2003 г. он с успехом прошел стажировку в США по программе «Сохранение памятников истории и культуры», организованной под эгидой Госдепартамента США.

В эти же годы Р.И. Якупов участвовал в ряде прикладных проектов, в частности, по созданию заповедника «Аслы-куль». Являясь ответственным секретарем коллективного исследования «Народы Башкортостана: историко-этнографические очерки», Риф Исмагилович внес значительный вклад в подготовку и публикацию данной монографии. Он также успешно работал над совместными проектами с Институтом этнологии РАН (г. Москва) в области этноэкологии, этносоциологии, вел научно-методологические семинары в Отделе народов Урала и другую научную работу. 
Мигранова Э.В. «Жаль, что мы всегда осознаем потери спустя время»

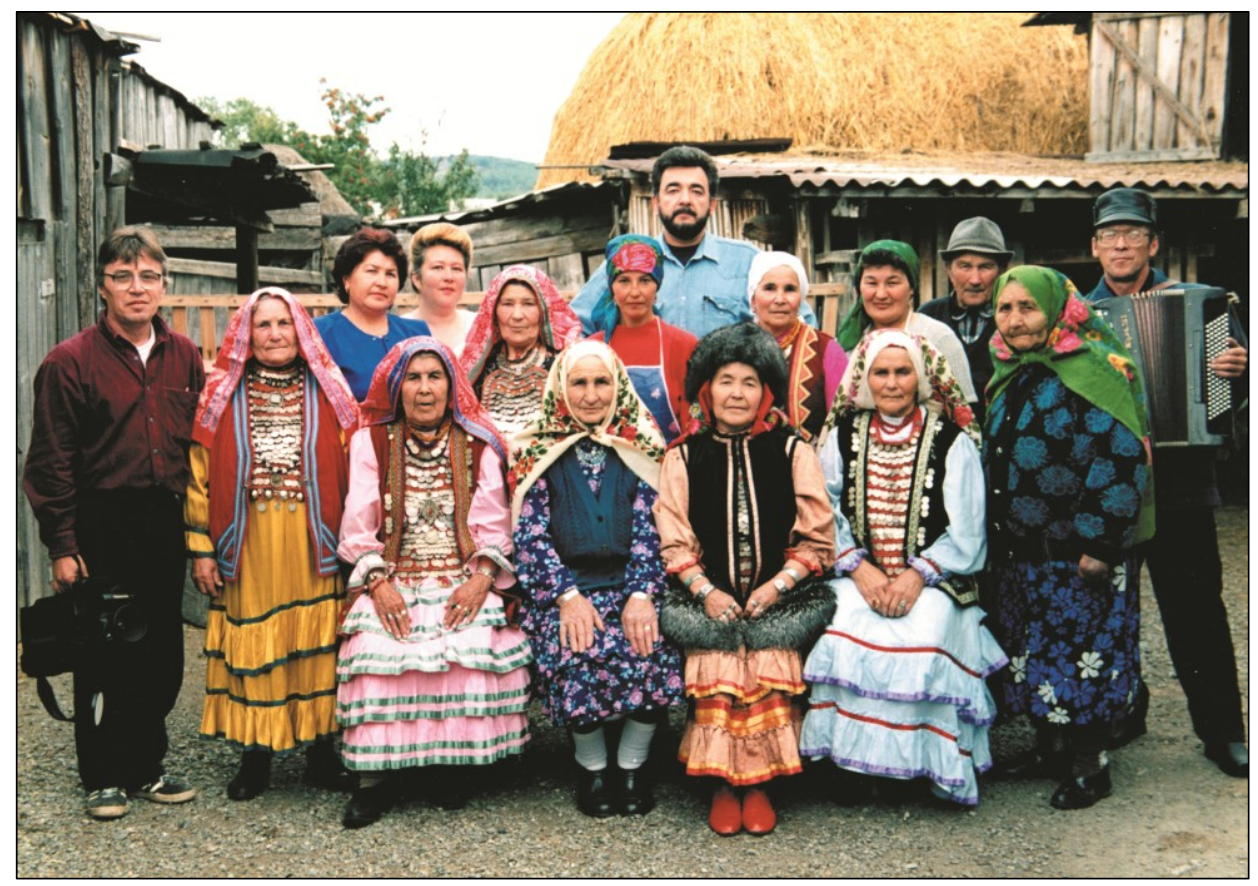

В этнографической экспедиции. Учалинский район. 1997 (?) г.

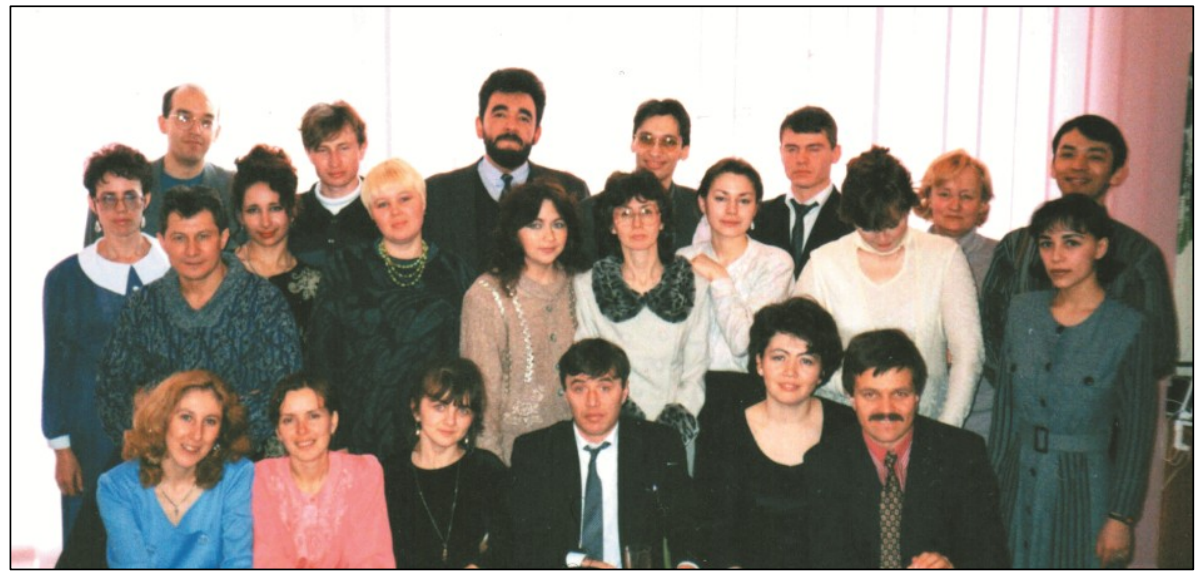

Среди коллег. Сотрудники Центра этнологических исследований Уфимского научного центра РАН. 1997 г.

После окончания аспирантуры в 1993 г. по предложению Р.Г. Кузеева, Р.И. Якупов возглавил сектор этнологии в ОНУ. С 2001 г. по 2003 гг. Р.И. Якупов - заместитель директора Центра этнологических исследова- 
ний с Музеем археологии и этнографии УНЦ РАН по научной работе. На этой должности он как ученый-этнолог немало способствовал активному развитию и центра, и музея.

В 2003 г. Р.И. Якупов был назначен деканом факультета истории и права Восточного института экономики, гуманитарных наук, управления и права (ВЭГУ). Одновременно он является заведующим кафедрой Всемирной истории этого университета.

С 2005 г. и до последних дней жизни Риф Исмагилович - ведущий научный сотрудник Института истории, языка и литературы УНЦ (ныне УФИЦ) РАН. Он являлся Членом Ассоциации этнологов и антропологов России (АЭАР) с 1990 г. (в том числе Председателем регионального отделения АЭАР в 1995-2003 гг.), Членом Общества Востоковедов РАН с 2000 г., Членом Российского географического общества с 2017 г. и т.д. В разные годы он входил в состав многих Ученых Советов: Центра этнологических исследований (1993-2003 гг.), исторического факультета БГПУ (1996-2003 гг.), ВЭГУ (2003-2007 гг.), Ордена Знак Почета Института истории, языка и литературы (2009-2019 гг.), Российского исламского университета (2007-2019 гг.). В 2010 г. Риф Исмагилович был избран Членом Совета по исламскому образованию при Совете муфтиев России, а также Членом Экспертного совета при Министерстве образования и науки РФ по разработке и внедрению учебного курса «Основы религиозных культур и светской этики». Кроме того, он был Членом экспертного Совета ВАК по специальности «Теология», проректором и преподавателем Российского исламского университета; членом редколлегии ВАКовского журнала Minbar. Islamic Studies, главным редактором, членом редколлегии и редсовета научно-теологического альманаха Дары знаний» (Уфа), международного «Дайджест-Бюллетеня РИУ ЦДУМ России» и т.д.

Р.И. Якупов - участник многочисленных (более 100) региональных, всероссийских и международных научных конференций; в том числе, Конгрессов этнографов и антропологов России; один из разработчиков Государственной программы «Народы Башкортостана»; член редколлегий авторитетных журналов и сборников, среди которых сборники «Мировое сообщество» (Уфа); «История и современность» (Москва); газета «Татарский мир» и ее приложение «Восток» (Москва); журнал ВАК «Вестник ВЭГУ» (Уфа) и др.

Подготовленные профессором Р.И. Якуповым научные кадры (выпускники вузов, аспиранты, кандидаты наук) свидетельствуют, что Риф Исмагилович является и основателем собственной научной школы. Адекватным отражением достижений в области науки и образования стало присвоение Рифу Исмагиловичу в 2004 г. ученого звания профессора. 
Мигранова Э.В. «Жаль, что мы всегда осознаем потери спустя время»

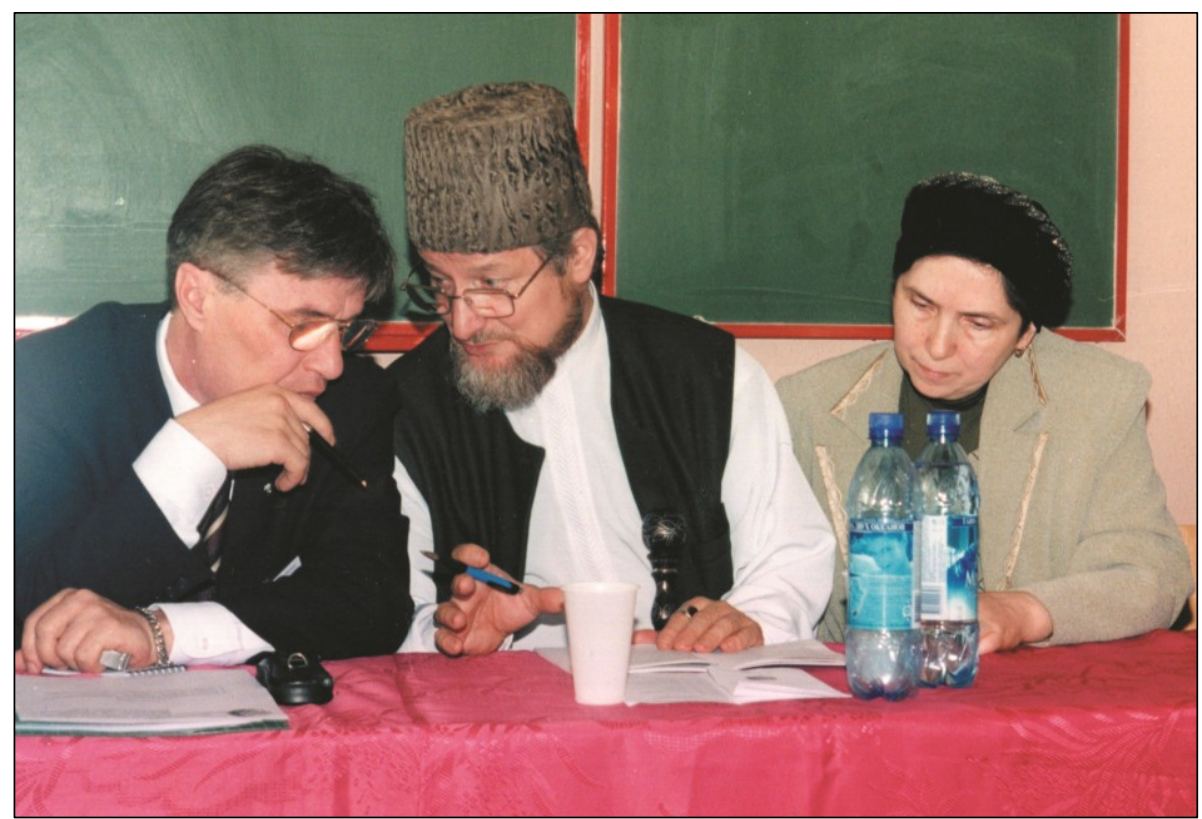

Р.И. Якупов и муфтий Талгат Сафич Таджутдин.

Региональная научно-практическая конференция «Личность, общество, государство, религия: взаимодействие и противоречия». Уфа, 2003 г.

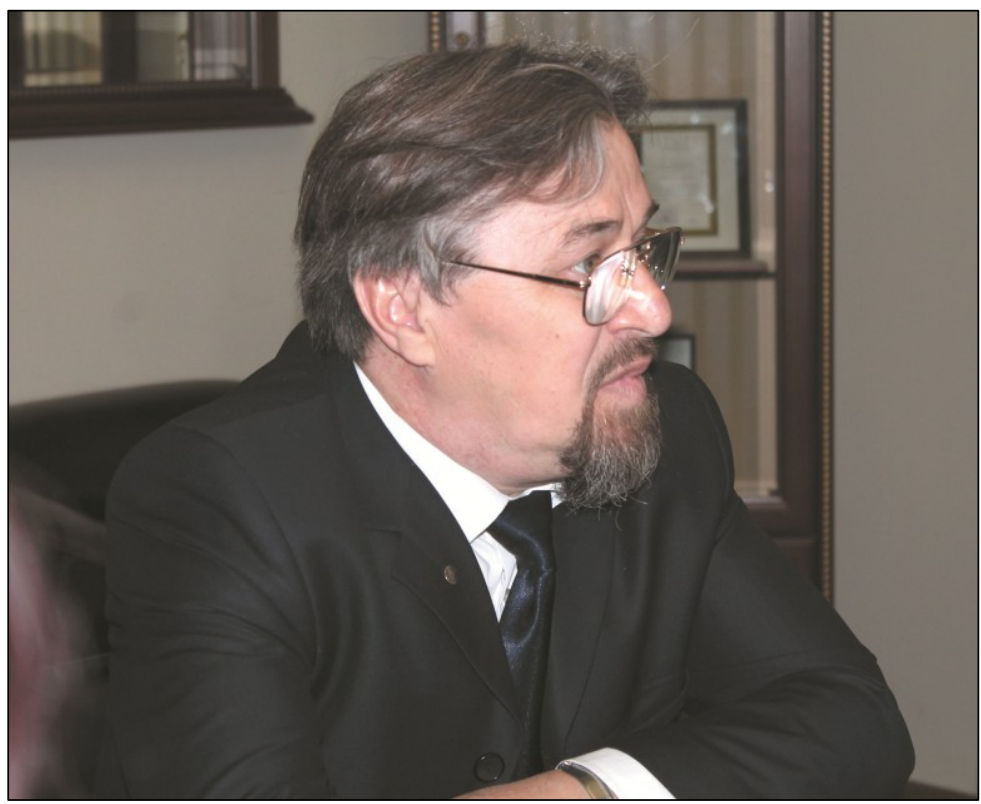

III Кузеевские чтения в Институте этнологических исследований УНЦ РАН. Октябрь 2012 г. 
Как этнограф Р.И. Якупов совмещал кабинетную работу с ежегодными полевыми выездами, в том числе в качестве начальника экспедиций. Особое внимание исследователь уделял сбору материала среди тептярей главного объекта своих научных изысканий.

Занявшись этнографией еще в институте, Риф Исмагилович больше уже не изменял своему увлечению. Р.И. Якупов - автор почти 200 научных публикаций, в том числе пяти монографий: «Тептяри: этносоциальный феномен и научная проблема» (Уфа, 1998), «Тептяри: историкоэтнографические очерки: к проблеме генезиса этничности» (М., 2002), «В поисках традиционной культуры: архивно-этнографическая эвристика на материалах ЦИА РБ» (Уфа, 2012), «Архив - как экспериментальная база исследователя: историко-дидактические очерки» (Уфа, 2016) и «Из истории духовного образования: от медресе "Галия" до "Российского исламского университета": к 110 летнему юбилею» (Уфа, 2016); многочисленных коллективных монографий, в числе которых семитомная «История башкирского народа»; учебно-методических и справочных работ, курсов лекций и т.д.; а также десятков научных статей, некоторые из которых написаны на английском языке. Кроме того, Риф Исмагилович был ответственным редактором почти 40 монографий и коллективных трудов, членом редколлегии многочисленных научных изданий. В числе последних: «Этносы и природа: проблемы этноэкологии» (1998); «Народы Башкортостана: историко-этнографические очерки» (2002); «Евразийство: проблемы осмысления» (2002); «Личность, общество, государство, религия: взаимодействие и противоречия» (2003); «Взаимодействие этносов на Южном Урале: комплексные этнолого-антропологические исследования» (2006); «Институт истории, языка и литературы: время, открытия, люди» (2007); «Институт истории, языка и литературы: флагман гуманитарной науки Башкортостана» (2017) (два последних сборника были выпущены к 75- и 85-летию ИИЯЛ); «Народы Южного Урала в этносоциальном измерении. Башкиры, татары, русские в последней четверти XX в.» (2010) и др. Буквально на днях, уже после смерти Рифа Исмагиловича, увидела свет коллективная монография «Этносы и культуры в единой семье Башкортостана», в которой он был автором статьи о татарах.

Темы, которыми на протяжении жизни занимался Р.И. Якупов, представляются чрезвычайно интересными и актуальными, как для российской, так и для мировой этнологии в целом. Область его научных интересов чрезвычайно обширна: это и этнология, и историография, и источниковедение, и музееведение, и исламоведение, и науковедение, и лингвистика, и история государства и права, и общая педагогика и т.д. Особое внимание, однако, Риф Исмагилович уделял вопросам теории этноса, методологии исследований, фундаментальным проблемам культурологии, этногенезу и этнической истории башкир, татар, тептярей и других народов Волго-Уральской историко-этнографической области. 
Кандидатская диссертация Р.И. Якупова «Проблема тептярей в историко-этнографической литературе XVIII-XX вв.», защищенная в 1996 г. в Совете при Музее археологии и этнографии им. Петра Великого (Кунсткамера) РАН (г. Санкт-Петербург), была выполнена на стыке историографии и этнографии. В ней в значительной степени проявился интерес молодого соискателя к проблемам истории науки и источниковедения. А в своей фундаментальной докторской диссертации «Тептяри: Проблема формирования этничности», защита которой состоялась в 2001 г. в Совете Института этнологии и антропологии РАН (г. Москва), Риф Исмагилович, рассматривая в историческом плане генезис тептярей, уже вплотную подошел к вопросам теории этноса. Главной проблемой для исследователя было то, как идентифицировать эту общность. Как социум (сословие), как этнос (народ), субэтнос (часть народа, этнографическая группа) или как нечто еще? Прежде всего, он заострял внимание на концепции этноса, его природе, раскрывал законы развития этноса, останавливался на изучении этнических процессов и механизмов их протекания, факторов, влияющих на этнические процессы и многом другом. После определенных усилий, а именно после реконструкции их истории, ученый пришел к выводу, что процесс формирования тептярей может и должен рассматриваться как модель этногенетических и этнокультурных процессов. Предложенная в этой работе модель генезиса этничности в новое и новейшее время чрезвычайно интересна и важна для теоретической этнологии в целом. Рассуждая об этногенезе и этнической истории, ученый призывал четко различать, где еще идут этногенетические процессы, а где уже идет процесс этнической порциации (выделения новых этносов из существующих).

В своих трудах Якупов спорил с конструктивистами, которые, на его взгляд, подчас отказывают этносу в объективности и, как правило, рассматривают его как один из типов социальной общности, в которой предполагается личный выбор индивида в его социализации и вхождении в различные среды и сообщества, в том числе этнические.

Темы, затронутые в работах Рифа Исмагиловича, сколь сложны, столь и необъятны. Ученый говорил, что этнос - и прост, и сложен, прежде всего потому, что этносы - это все мы. Всякий человек является представителем своего народа и ему кажется, что как минимум о своем народе он знает практически все, а потому какие там еще могут быть загадки? Но все это иллюзия, - предупреждал исследователь. Этнос - это сложный объект, сложная система, сложный механизм, над его пониманием трудилось и трудится не одно поколение ученых. Р.И Якупов искал и находил закономерности взаимосвязей различных элементов этноса, а показанный ученым механизм формирования, сохранения и трансформации этнических общностей, позволяет глубже понять перспективы этнокультурного развития в России и влияния этнического фактора на все стороны жизни российского общества. Общеизвестно, что этничность в России в силу ряда исторических причин, является важным фактором общественной жизни, и, видимо, еще долго будет играть роль в культурной, социальной и политической жизни. 
Историческая этнология. 2019. Том 4, № 2

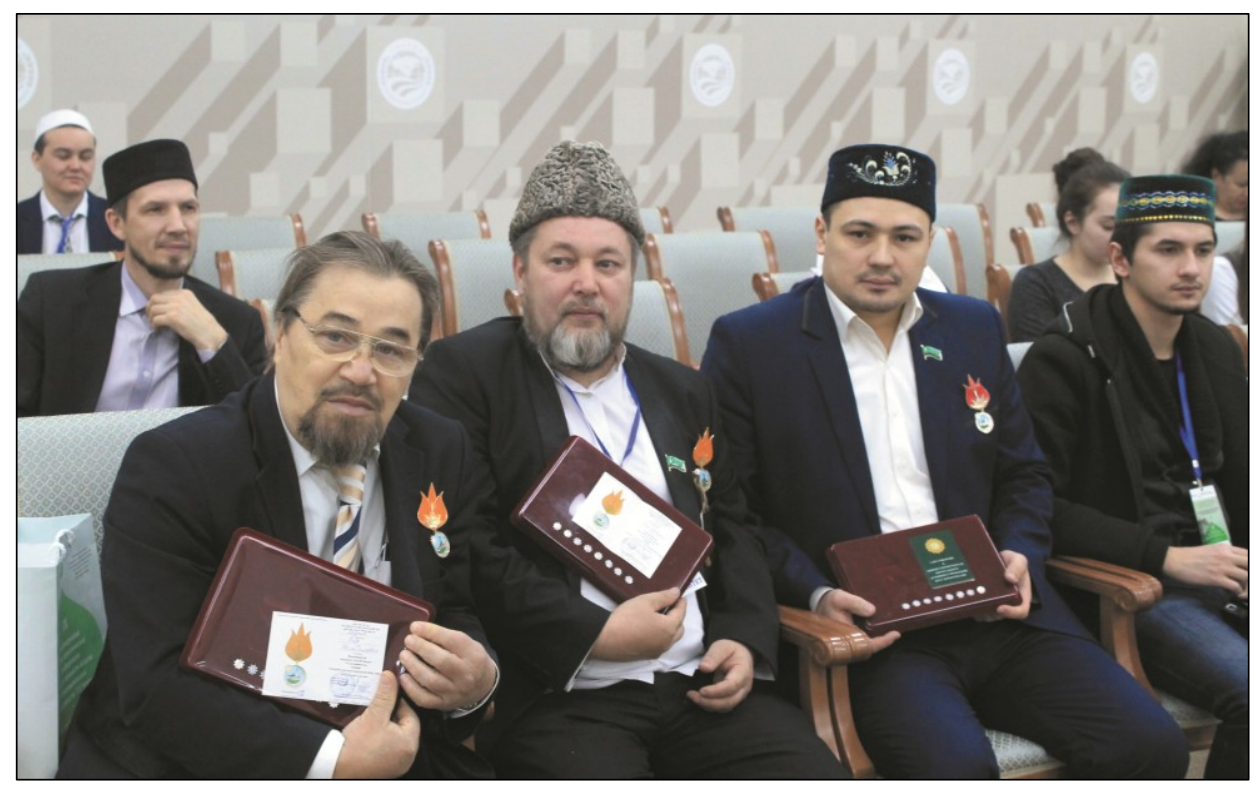

Награждение медалью и грамотой ЦДУМ Российской Федерации «За вклад в развитие духовного образования». 2016 г.

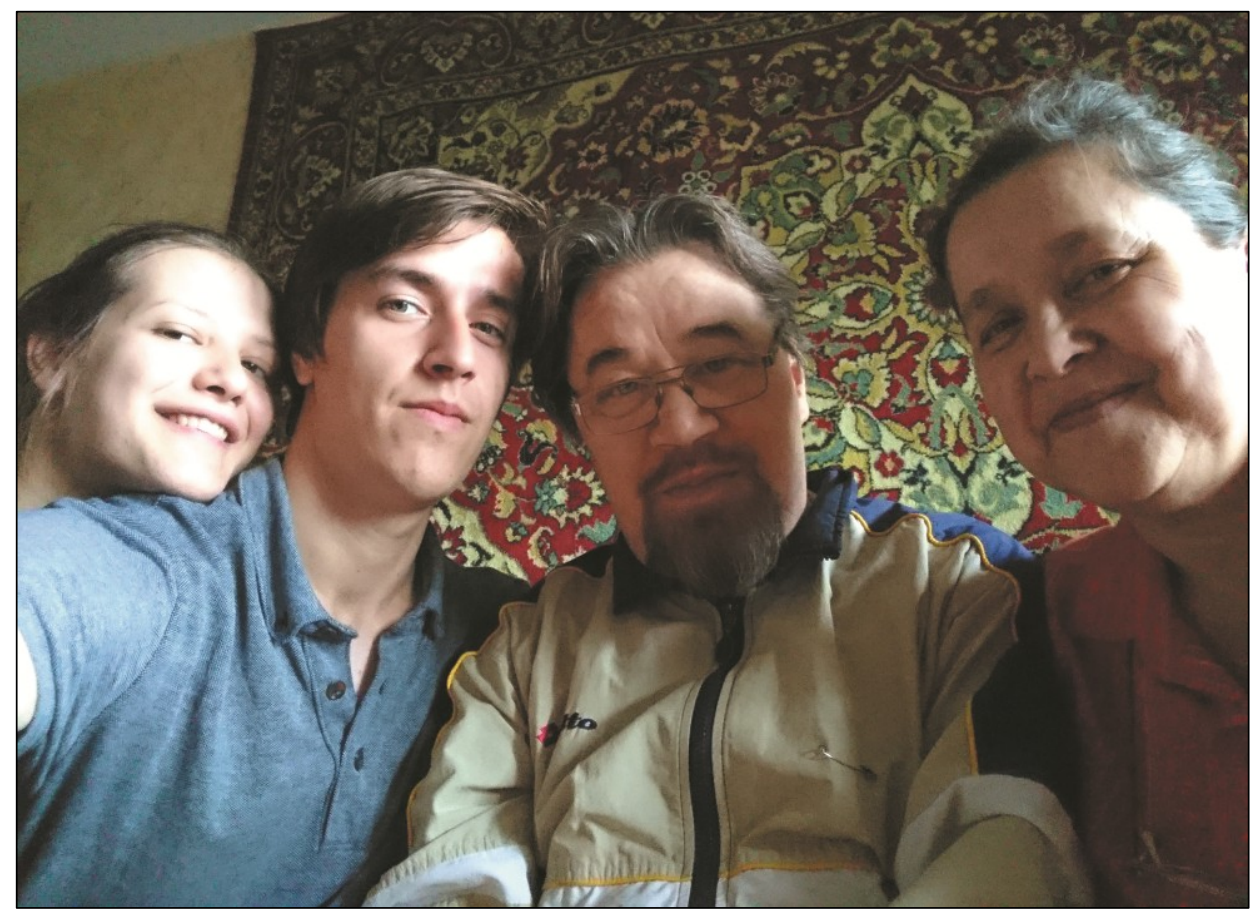

В кругу семьи. 2017 г. 
В монографии «В поисках традиционной культуры. Архивно-этнографическая эвристика на материалах ЦИА РБ» Р.И. Якупов дает практические рекомендации и предлагает методику анализа письменных материалов, которые до последнего времени весьма ограниченно (в отличие от полевых материалов) использовались в этнографических исследованиях и при изучении этногенетических и этноисторических процессов; приводит собственные методы поиска информации в архивах, делится алгоритмом анализа бесчисленного множества источников, выявления их культурографического содержания. Автор ввел в научный оборот новые понятия и термины, важнейший из которых «архивно-этнографическая эвристика», который, по мнению коллег ученых, вероятно, займет свое место в терминологии этнографической науки. В данной монографии ученый приоткрывает завесу над мастерской исторической и этнографической науки, ставит и успешно решает вопросы выявления и критического разбора архивных письменных и других визуальных источников, говорит о возможности их применения в гуманитарных науках, то есть практически дает специалистам и всем интересующимся историей и этнографией ключ к уникальным источникам как Национального архива Республики Башкортостан, так и архивов страны в целом.

...После перенесенного в 29 лет инфаркта Риф Исмагилович тяжело болел, его здоровье постоянно находилось под угрозой, особенно в последние годы, его часто увозили в реанимацию и буквально возвращали с «того света». Каждый день был для него борьбой за жизнь. Но, несмотря на болезнь, ученый продолжал плодотворно заниматься научной и преподавательской деятельностью, очень хотел жить, дождаться внуков. С его слов: «С этим нужно просто считаться, принять как есть. Не пугаться, не опускать рук. Но знать и понимать и строить свое бытие, извлекая максимум возможного из своего потенциала, который настолько огромен в человеке, что при определенных обстоятельствах, даже необратимые следствия отступают». В этом году доктору исторических наук, профессору Рифу Исмагиловичу Якупову исполнилось бы 60 лет.

К сожалению, не суждено было осуществиться множеству его задумок, планов и проектов. Но, к счастью, осталось его богатое научное и человеческое наследие, которое еще предстоит изучить и осмыслить новому поколению этнологов, культурологов, религиоведов. Когда-то Риф Исмагилович произнес «Жаль, что мы всегда осознаем потери спустя время». Да, действительно очень жаль...

В наших сердцах останется светлая память об ученом, жизнь которого без преувеличения была посвящена служению науке. 


\section{ОСНОВНЫЕ ТРУДЫ Р.И. ЯКУПОВА}

\section{Монографии:}

Тептяри: этносоциальный феномен и научная проблема. Уфа, 1998.

Тептяри: историко-этнологические очерки. К проблеме генезиса этничности. M., 2001.

В поисках традиционной культуры. Архивно-этнографическая эвристика на материалах ЦИА РБ. Уфа, 2013.

Архив - как экспериментальная база исследователя. Историко-дидактические очерки. Уфа, 2016.

Из истории мусульманского высшего образования. От медресе «Галия» до Российского Исламского Университета ЦДУМ России. К 110 летнему Юбилею. Уфа, 2016.

Введение в общую этнологию. Уфа, 2016.

\section{Cmambu:}

Тептяри: сословие или этнос // Этнос и его подразделения. Ч. 2. Этнические и этнографические группы в Волго-Уральском регионе. М., 1992. С. 165-170.

О концепции Евразийства // Вестник АН РБ. № 4. 1998. С. 67-73.

Краткий очерк развития этнографии Башкортостана // Вестник ВЭГУ. 2007. № 31/32. С. 152-161.

Этносы и этничность в начале XXI в. // Вестник ВЭГУ. 2008. № 6 (38). C. 47-51.

Как осмысливалась этническая история Евразии (памяти Р.Г. Кузеева) // Этнографическое обозрение. 2010. № 2. С. 110-119.

Российская школа теории этноса: Историографическое обоснование // От племени к этносу. Этнография в Русском географическом обществе. Под ред. А.В. Псянчина. Вып. 2. СПб., 2015. С. 7-22.

Традиционный ислам: терминология и риторика // Традиционный ислам: понятие, сущность и содержание. Уфа, 2015. С. 30-37 и др.

\section{Статьи о нем:}

Якупов Риф Исмагилович // Музей археологии и этнографии. Уфа, 2007. C. 27.

Кулешов Д. Путь ученого // Грани познания. 2009. №7/8. С. 189- 192.

Якупов Риф Исмагилович // Башкирская энциклопедия: [В 7 т.]. Уфа, 2011. T. 7. С. 447-448.

Якупов Риф Исмагилович // Народы Башкортостана: Энциклопедия. Уфа, 2014. С. 449-450 и др.

Сведения об авторе: Мигранова Эльза Венеровна - кандидат исторических наук, старший научный сотрудник отдела этнологии Ордена Знак Почета Института истории, языка и литературы Уфимского федерального исследовательского центра Российской академии наук (450054, Проспект Октября, 71, Уфа, Российская Федерация); mig.el@mail.ru 


\title{
“IT'S A PITY THAT WE RECOGNIZE LOSSES ONLY LONG AFTER"
}

\author{
E.V. Migranova \\ Order of the Badge of Honour Institute of history, language and literature \\ of the Ufa Federal Research Centre of the Russian Academy of Sciences \\ Ufa, Russian Federation \\ mig.el@mail.ru
}

This memorial article is devoted to the description of the life, research and pedagogical work of the schola and ethnologist Rif Ismagilovich Yakupov, who died prematurely, made a significant contribution to the study of theoretical issues of the ethnos theory, solving the problems of the formation and historical development of tepars, studying archival affairs in the Republic of Bashkortostan and other urgent problems of modern ethnological science.

Keywords: Rif Ismagilovich Yakupov, scientist, ethnologist, teacher, ethnos theory, teptyari.

For citation: Migranova E.V. "It's a pity that we recognize losses only long after". Istoricheskaya etnologiya - Historical Ethnology, 2019, vol. 4, no. 2, pp. 386-398. DOI: 10.22378/he.2019-4-2.386-398

\section{R.I. YAKUPOV'S FUNDAMENTAL WORKS}

\section{Monographs:}

Teptyari: etnosocial'nyj fenomen i nauchnaya problema [The Teptyars: An ethnosocial phenomenon and a scientific problem]. Ufa, 1998 (In Russian).

Teptyari: istoriko-etnologicheskie ocherki. K probleme genezisa etnichnosti [The Teptyars: Historical-ethnilogical essays. On the problem of genesis of ethnicity]. Moscow, 2001 (In Russian).

$V$ poiskah tradicionnoj kul'tury. Arhivno-etnograficheskaya evristika na materialah CIA RB [Searching for traditional culture. Archive and ethnographic evristics based on the materials of the Republic of Bashkortostan Central Historical Archive]. Ufa, 2013 (In Russian).

Arhiv - kak eksperimental'naya baza issledovatelya. Istoriko-didakticheskie ocherki [Archive as a researcher's experimental base. Historical-didactic essays]. Ufa, 2016 (In Russian).

Iz istorii musul'manskogo vysshego obrazovaniya. Ot medrese «Galiya» do Rossijskogo Islamskogo Universiteta CDUM Rossii. K 110 letnemu YUbileyu. Ufa, 2016 (In Russian).

Vvedenie v obshchuyu etnologiyu. Ufa, 2016 (In Russian).

Articles:

Teptyari: soslovie ili etnos // Etnos i ego podrazdeleniya. Ch. 2. Etnicheskie i etnograficheskie gruppy v Volgo-Ural'skom regione. M., 1992. S. 165-170 (In Russian). 
O koncepcii Evrazijstva [On the concept of Eurazianism].. Vestnik AN RB - Bulletin of the Republic of bashkortostyan Academy of Sciences, 1998, no. 4, pp. 67-73 (In Russian).

Kratkij ocherk razvitiya etnografii Bashkortostana [A short essay on the development of Bashkortostan ethnography]. Vestnik VEGU - Vestnik of VESU. 2007, no. 31/32, pp. 152-161 (In Russian).

Etnosy i etnichnost' v nachale XXI veka [Ethnos and ethnicities in early 21 st century], Vestnik VEGU - Bulletin of VESU, 2008, no. 6 (38), pp. 47-51 (In Russian).

Kak osmyslivalas' etnicheskaya istoriya Evrazii (pamyati R.G. Kuzeeva) [How the ethnic history of Eurasia was comprehended (in memory of R.G. Kuzeeva)]. Etnograficheskoe obozrenie - Ethnigraphoic Review. 2010. no.2, pp. 110-119 (In Russian).

Rossijskaya shkola teorii etnosa: Istoriograficheskoe obosnovanie [The Russian school of the ethnos theory: Historiographic foundation]. Ot plemeni $k$ etnosu. Etnografiya $v$ Russkom geograficheskom obshchestve [From a tribe to ethnos. Ethnography i the Russian geographocal society]. Ed. A.V. Psyanchina. Issue. 2. St. Petersbirg, 2015, pp. 7-22 (In Russian).

Tradicionnyj islam: terminologiya i ritorika [Traditional Islam: terminology and posturing]. Tradicionnyj islam: ponyatie, sushchnost' $i$ soderzhanie [Traditional Islam: the notion, essence amd content]. Ufa, 2015, pp. 30-37 (In Russian) etc.

Articles about him:

Yakupov Rif Ismagilovich. Muzej arheologii i etnografii [The Museum of Archeology and Ethnography]. Ufa, 2007. P. 27 (In Russian).

Kuleshov D. Put' uchenogo [The parth of a scholar]. Grani poznaniya - The Verge of Knowledge. 2009, no.7/8, pp. 189-192 (In Russian).

Yakupov Rif Ismagilovich. Bashkirskaya enciklopediya. V 7 t. [The Bashkir Encyclopedia. In 7 vol.]. Ufa, 2011. Vol. 7. Pp. 447-448 (In Russian).

Yakupov Rif Ismagilovich. Narody Bashkortostana: Enciklopediya [Peoples of Bashkortostan: Encyclopedia]. Ufa, 2014, pp. 449-450 (In Russian) etc.

About the author: Elza V. Migranova is a Candidate of Science (History), Senior Researcher Fellow of the Department of Ethnology, Order of the Badge of Honour Institute of history, language and literature - Subdivision of the Ufa Federal Research Centre of the Russian Academy of Sciences (71, Prospect of October, Ufa 450054, Russian Federation); mig.el@mail.ru 